\title{
PENGEMBANGAN MODUL FISIKA BERBASIS DISCOVERY LEARNING PADA MATERI FLUIDA STATIS SISWA KELAS XI SMA NEGERI 1 LUBUKLINGGAU LUBUKLINGGAU TAHUN PELAJARAN 2019/2020
}

\author{
Nadia Apriyani ${ }^{1}$, Tri Ariani, ${ }^{2}$ Wahyu Arini $^{3}$ \\ nadialinggau1106@gmail.com \\ ${ }^{1,2,3}$ Program Studi Pendidikan Fisika STKIP PGRI Lubuklinggau, Sumatera Selatan, Indonesia
}

Received: 31 Mei 2020

Revised: 1 Juni 2020

Accepted:15 Juni 2020

\begin{abstract}
All The All objectives of the reserch was to develop the Physics module with discovery learning on Static Fluid Material that is valid, practical and effective. The subjects in this study were the entire class XI Natural Sciences and the broad group research subjects in this study were the XI MIPA 4 class of SMA Negeri 1 Lubuklinggau in the 2019/2020 Academic Year consisting of 36 students taken by simple random sampling technique. Data collection was carried out using questionnaire and test techniques. Validation is done to get results with a good category that is with a percentage of $78.81 \%$. Student responses to the discovery learning based module were $88.25 \%$. Besides that from the results of daily tests conducted, it was found that student learning outcomes were completed with an average of 83.8. As well as the average percentage of student activity at the time of practicum which is $71.4 \%$ included in both categories. The value of t table with degrees of freedom $(\mathrm{dk})=n-1=36-1=35$ and $\alpha=0.05 t_{\text {coun }} t=2.95$ and $t_{\text {table }}=1.689$ because $t_{\text {count }} \geq t_{\text {table }}$ then $H_{a}$ is accepted. So it can be said that the Discovery Learning-based Module that was developed has been valid, practical, and effective.
\end{abstract}

\begin{abstract}
Abstrak: Penelitian ini bertujuan untuk mengembangan Modul Fisika Berbasis Discovery Learningpada Materi Fluida Statis yang valid, praktis dan efektif. Subjek dalam penelitian ini adalah seluruh kelas XI IPA dan subjek penelitian kelompok luas dalam penelitian ini adalah kelas XI MIPA 4 SMA Negeri 1 Lubuklinggau Tahun Pelajaran 2019/2020 yang terdiri dari 36 siswa yang diambil dengan teknik simple random sampling. Pengumpulan data dilakukan dengan teknik angket dan tes. Validasi yang dilakukan mendapatkan hasil dengan kategori baik yaitu dengan presentase 78,81\%. Respon siswa terhadap modul berbasis discovery learningyaitu 88,25\%. Selain itu dari hasil tes ulangan harian yang dilakukan, didapatkan bahwa hasil belajar siswa tuntas dengan ratarata 83,8. Serta persentase rata-rata aktivitas siswa pada saat praktikum yaitu 71,4\% termasuk kedalam kategori baik. Nilai $t_{\text {tabel }}$ dengan derajat kebebasan $($ dk) $=n-1=36-1=35$ dan $\alpha=0,05$ $t_{\text {hitung }}=2,95$ dan $t_{\text {tabel }}=1,689$ karena $t_{\text {hitung }} \geq t_{\text {tabel }}$ maka $H_{a}$ diterima. Sehingga dapat dikatakan bahwa Modul berbasis discovery learningyang dikembangkan telah valid, praktis, dan efektif.
\end{abstract}

Kata kunci : Discovery Learning, Modul, Pengembangan.

\section{PENDAHULUAN}

Kemajuan teknologi dan ilmu pengetahuan berkembang sangat pesat disertai semakin meningkatnya sumber daya manusia yang berkualitas. Sistem Pendidikan di Indonesia senantiasa berubah-ubah dari waktu ke waktu. Pendidikan merupakan salah satu faktor yang dapat meningkatkan mutu sumber daya manusia di Indonesia dan sangat berperan penting dalam menyiapkan sumber daya manusia (Yuliani, N., Amin, A., \& Arini, W, 2019). Wahyudin (dalam Triyanto 2018) bahwa pendidikan adalah suatu proses humanisasi yang Puplished at https://ojs.stkippgri-lubuklinggau.ac.id/index.php/SJPIF 
dimana suatu upaya dalam rangka membantu manusia agar mampu hidup sesuai dengan martabat kemanusiannya. Pendidikan merupakan investasi jangka panjang yang bila dikelola dengan baik dapat mencerdaskan kehidupan suatu bangsa. Pendidikan merupakan wadah para siswa mencari ilmu, mengembangkan potensi yang mereka miliki baik potensi akademis maupun potensi non akademis. Proses pendidikan tidak dapat dipisahkan dari proses pembangunan itu sendiri. Pembangunan dalam pendidikan diarahkan dan bertujuan mengembangkan sumber daya manusia yang berkualitas (Ariani, T, 2017). Seiring dengan hal tersebut berbagai upaya telah dilakukan oleh Kemendiknas untuk mewujudkan kualitas dan mutu pendidikan yang lebih baik. Salah satu upaya yang dilakukan oleh Kemendiknas adalah pengembangan kurikulum. Kemendiknas selalu melakukan pengembangan kurikulum sesuai dengan tuntutan zaman, dari kurikulum 1947 hingga kurikulum 2013 (K13) yang selalu direvisi sampai sekarang. Dalam kurikulum 2013 (K13), peserta didik dituntut untuk lebih aktif dalam proses pembelajaran dan guru hanya berperan sebagai fasilitator dan motivator (Lorenza, Y., Sasmita, P. R., \& Amalia, S, 2019).

Perkembangan pada zaman sekarang ini dimana era globalisasi dan kualitas peradabannya, tidak pernah lagi difokuskan pada kekuatan sumber daya alam secara utuh melainkan sangat diperlukan manusia-manusia yang mampu mengembangkan suatu produk atau komponen yang penting dalam pelaksanaan pembelajaran yaitu melalui suatu pengembangan modul. Dalam kurikulum saat ini dengan menciptakan suatu modul dengan membantu siswa lebih aktif dalam pembelajaran dengan membuat siswa dapat menemukan konsep beserta jawaban sendiri dan membuat siswa merumuskan masalah baik itu masalah secara eksperimen, diskusi, ataupun praktikum (Ayu, W. R., Ariani, T., \& Arini, W, 2019).

Berdasarkan hasil observasi yang dilakukan melalui wawancara dengan siswa kelas XI MIPA di SMA Negeri 1 Lubuklinggau, hasil wawancara yang pertama dengan beberapa siswa kelas XI MIPA SMA Negeri 1 Lubuklinggau mengungkapkan bahwa fisika merupakan mata pelajaran yang berhubungan dengan perhitungan dan gambar namun juga menyangkut dengan fenomena alam yang ada di kehidupan sehari-hari, tapi ada juga yang mengatakan bahwa fisika merupakan pelajaran yang menakutkan, sulit dipahami dan membosankan karena fisika selalu dikaitkan dengan rumus-rumus yang sangat banyak beserta contoh soal dengan evaluasi yang berbeda dan memang sangat mustahil untuk dihafal semuanya. Di samping itu proses pembelajaran fisika di sekolah yang memang dilakukan oleh semua guru di SMA Negeri 1 Lubuklinggau sudah menerapkan metode pembelajaran K13, akan tetapi 
pada saat yang bersamaan ketika ingin menerapkan pembelajaran guru tersebut masih menggunakan metode konvensional.

Dalam hal tersebut berkaitan proses pembelajaran bahan ajar yang digunakan disekolah masih berasal dari cetakan yang sudah ada seperti menggunakan LKS seri pengayaan fisika kelas XI penerbit yudhistira dan buku cetak siswa aktif dan kreatif belajar fisika kelas XI penerbit grafindo. Dalam hal ini dapat dikatakan oleh guru memang proses pembelajaran belum menggunakan bahan ajar yang berupa modul hanya buku cetak dan LKS saja, tetapi dengan adanya bahan ajar tersebut tidak memungkinkan bagi siswa dan guru untuk tidak menggunakan bahan ajar tersebut, namun sebaiknya bahan ajar yang digunakan dalam pembelajaran dibuat langsung oleh guru yang bersangkutan sehingga bisa mempermudah siswa untuk menangkap pembelajaran yang dilaksanakan.

Penggunaan modul fisika berbasis discovery learning ini membuat siswa akan lebih tertarik dan bisa mengerti materi dengan mudah karena semua permasalahan yang dihadapi oleh siswa semuanya bisa diatasi sendiri oleh siswa. Dengan menemukan sendiri jawaban dari permasalahan siswa menjadi lebih mudah dalam mengingat pelajaran dan lebih semangat dalam membangun pengetahuan yang lebih lagi. Penerapan model pembelajaran discovery learning pada pembelajaran sains saat ini sangat dianjurkan untuk melibatkan siswa dalam proses belajar secara aktif, sehingga apa yang dihadapi siswa ketika belajar tidak lagi menjadi subjek yang pasif yang hanya duduk, diam, ribut, mengantuk, hanya fokus mendengarkan saja, serta gagal dalam menyelesaikan soal-soal yang memang sulit bagi mereka dan siswa akan lebih mampu lagi dalam mengasah pemahamannya.

Berdasarkan latar belakang yang diuraikan diatas dan dengan melihat situasi, kondisi dan kenyataan yang ada mengenai permasalahan yang terjadi di sekolah maka peneliti tertarik untuk mengangkat judul "Pengembangan Modul Fisika Berbasis Discovery Learning pada Materi Fluida Statis Siswa Kelas XI SMA Negeri 1 Lubuklinggau Tahun Pelajaran 2019/2020”. Tujuan dari dilakukannya penelitian ini adalah: 1) Mengembangkan modul fisika berbasis discovery learning untuk siswa kelas XI SMA Negeri 1 Lubuklinggau Tahun Pelajaran 2019/2020,2) Mengetahui karakteristik modul fisika berbasis discovery learning yang dikembangkan memenuhi sasaran kevalidan, kepraktisan, dan keefektifan pada kelas XI SMA Negeri 1 Lubuklinggau Tahun Pelajaran 2019/2020.

\section{LANDASAN TEORI}

1. Model Pengembangan 
Metode penelitian dan pengembangan adalah metode penelitian yang digunakan untuk menghasilkan produk tertentu, dan menguji keefektifan produk tersebut dan dapat bertujuan atau diarahkan untuk mencari temukan, merumuskan,memperbaiki, mengem-bangkan, menghasilkan, menguji keefektifan produk.

Dalam hal ini bahan ajar yang akan di kembangkan yaitu modul, dari banyaknya model yang sudah dikembangkan maka dalam penelitian pengembangan ini, desain model pengembanganyangdigunakan adalah model 4D. Dalam rancangan model pengembangan 4D terdiri atas 4 langkah, yaitu define, design, develop dan desseminateatau diadaptasikan menjadi model 4P, yaitu pendefinisan, perancangan, pengembangan dan penyebaran.

Adapun bagan langkah-langkah penelitian berdasarkan model pengembangan 4D seperti ditunjukkan pada gambar berikut:

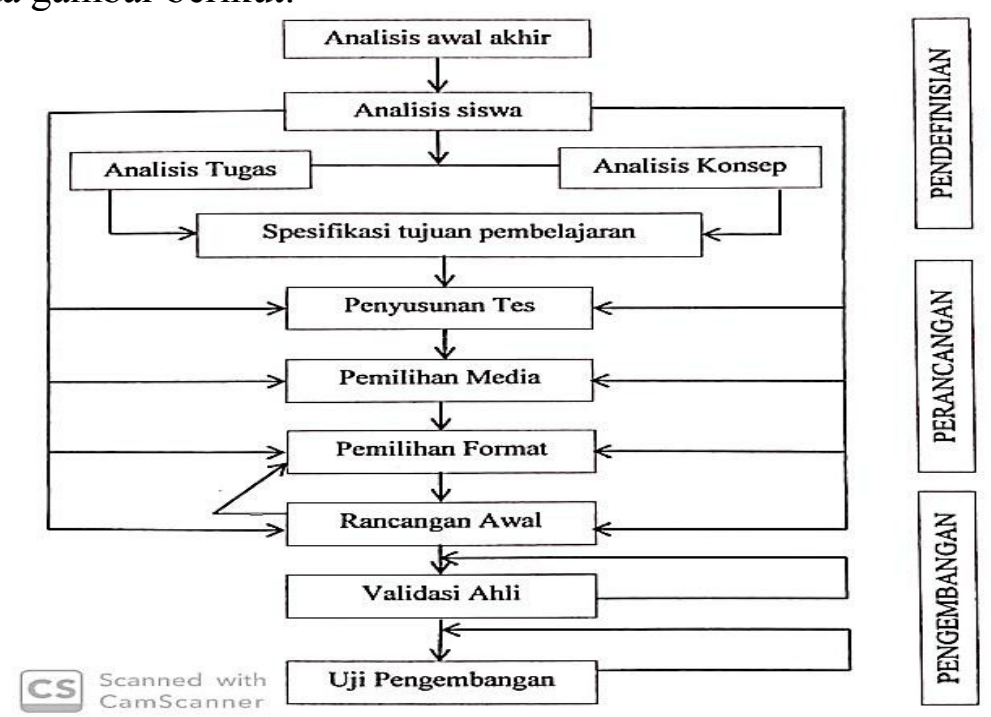

Gambar 1. Model perancangan danpengembangan pengajaran menurut 4D

\section{Modul}

Daryanto (2013) modul merupakan salah satu bentuk bahan ajar yang dikemas secara utuh dan sistematis, didalamnya memuat seperangkat pengalaman belajar yang terencana dan didesain untuk membantu peserta didik menguasai tujuan belajar yang spesifik yang memuat tujuan pembelajaran, materi/substansi belajar, dan evaluasi serta fungsi dari modul sebagai sarana belajar yang bersifat mandiri, sehingga peserta didik dapat belajar secara mandiri secara dengan kecepatan masing-masing. Istilah modul dipinjam dari dunia teknologi, yaitu alat ukur yang lengkap dan merupakan satu kesatuan program yang dapat mengukur tujuan.

Sedangkan menurut Nasution (2000) modul dapat dirumuskan sebagai satu unit yang lengkap yang berdiri sendiri dan terrdiri atas suatu rangkaian kegiatan belajar yang disusun untuk membantu siswa mencapai sejumlah tujuan yang dirumuskan secara khusus dan jelas.

Berdasarkan penjelasan diatas dapat disimpulkan bahwa modul adalah modul merupakan bahan belajar terprogram yang disusun sedemikian rupa dan disajikan secara terpadu, Puplished at https://ojs.stkippgri-lubuklinggau.ac.id/index.php/SJPIF 
sistematis, serta terperinci. Menurut Santyasa (dalam jurnal Rusmiati dkk, 2013) keuntungan yang diperoleh dari pembelajaran dengan penerapan modul adalah sebagai berikut: 1) meningkatkan motivasi peserta didik karena setiap kali mengerjakan tugas pelajaran yang dibatasi dengan jelas dan sesuai dengan kemampuan 2) setelah dilakukan evaluasi pendidik dan peserta didik mengetahui benar pada modul yang mana peserta didik telah berhasil dan pada bagian modul yang mana mereka belum berhasil 3) peserta didik mencapai hasil sesuai dengan kemampuannya 4) bahan pelajaran terbagi lebih merata dalam satu semester dan 5) pendidikan lebih berdaya guna karena bahan pelajaran disusun menurut jenjang akademik.

\section{Discovery Learning}

Joolingen dalam Rohim (dalam Jamillah dkk, 2017) menjelaskan bahwa discovery learning adalah suatu tipe pembelajaran dimana siswa membangun pengetahuan mereka sendiri dengan mengadakan suatu percobaan dan menemukan sebuah prinsip dari hasil percobaan tersebut. Model discovery learning melatih siswa untuk menemukan sendiri konsep-konsep dengan memberikan permasalahan yang harus di pecahkan siswa melalui modul yang akan di gunakan.

Menurut Brigenta dkk, (2017) Model pembelajaran discovery learning memiliki beberapa kelebihan, yaitu: 1) menambah pengalaman siswa dalam belajar, 2) memberikan kesempatan kepada siswa untuk lebih dekat lagi dengan sumber pengetahuan selain buku, 3) menggali kreatifitas siswa, 4) mampu meningkatkan rasa percaya diri pada siswa, dan 5) meningkatkan kerja sama antar siswa. Hal tersebut lebih didukung lagi berdasarkan beberapa hasil penelitian yang pernah dilakukan dengan menerapkan model pembelajaran discovery learning.

Adapun langkah-langkah pembelajaran dengan model discovery learning yaitu (1) memberikan stimulus kepada siswa, (2) mengindentifikasi permasalahan yang relevan dengan bahan pelajaran, (3) membagi siswa menjadi beberapa kelompok untuk melakukan diskusi, (4) memfasilitasi siswa dalam kegiatan pengumpulan data, (5) mengarahkan siswa untuk menarik kesimpulan berdasarkan hasil pengamatannya, (6) mengarahkan siswa untuk mengkomunikasikan hasil temuannya.

\section{METODE PENELITIAN}

Metode Penelitian yang digunakan adalah Research and Development (R\&D). Sugiyono (2012) menyatakan bahwa penelitian pengembangan (Research and Development)adalah metode penelitian yang digunakan untuk menghasilkan produk tertentu, dan menguji 
keefektifan produk tersebut. Penelitian ini menghasilkan produk berupa modul fisika berbasis discovery learning pada modul fisika untuk mencapai tujuan dan hasil belajar siswa dari segi kognitif.

Dalam penelitian ini untuk mengembangkan sebuah modul bebasis discovery learningpada materi fluida statis menggunakan model pengembangan 4D. dimana dalam penelitian ini mengadaptasi 3 langkah dari 4 langkah yang terdapat dalam model pengembangan 4D. Adapun langkah dari model pengembangan 4D terdapat 4 langkahn yaitu: define, design, develop, disseminate, namun peneliti hanya menggunakan 3. Rancangan dalam penelitian ini menggunakan desain One Shot Case Study dimana peneliti hanya melihat hasil akhir dari sebuah penelitian.

Populasi dalam penelitian ini adalah seluruh siswa kelas XI MIPA SMA Negeri 1 Lubuklinggau tahun pelajaran 2019/2020. Peneliti melakukan 3 tahap pengujian yaitu dengan menggunakan One To One, uji kelompok terbatas, uji kelompok luas. Pada uji One To One peneliti menggunakan angket dengan 3 orang siswa kelas XI MIPA 3, kemudian angket diberikan kepada 9 orang suswa kelas XI MIPA 6 pada uji kelompok terbatas. Angket ini berisi 10 pernyataan yang harus diberikan tanggapan oleh siswa. Pada akhirnya tahap uji coba kelompok luas dilakukan di kelas XI MIPA 4 SMA Negeri 1 Lubuklinggau dengan menggunakan 10 soal tes sebagai instrumen pengujian keefektifan produk. Dalam hal ini peneliti mengukur tingkat keefektifan dapat dilihat juga dari aktivitas praktikum siswa dimana untuk mengukur aktivias praktikum siswa digunakan lembar observer aktivitas praktikum siswa.

\section{Teknik Pengumpulan Data}

a. Wawancara

Wawancara dalam penelitian ini bertujuan untuk mendapatkan informasi studi pendahuluan dan untuk mengetahui modul fisika yang akan dikembangkan dengan menyusun beberapa pertanyaan yang ditanyakan kepada siswa dan guru.

b. Lembar Observasi Aktivitas Siswa

Syaodih (dalam Kusuma, 2016:368) observasi adalah suatu teknik dengan cara mengumpulkan data serta mengadakan pengamatan terhadap kegiatan yang sedang berlangsung baik secara langsung maupun tidak langsung. Pada lembar observasimemuat pertanyaan tentang yang mengaitkan keenam sintaks discovery learning dan berupa lembar kerja praktikum (LKP) pada saat praktikum disini digunakan untuk mengukur kemampuan 
siswa ranah kognitif dalam melakukan praktikum yang dibantu tim obsever untuk menilai siswa tersebut, dan bagaimana untuk melihat hasil aktivitas siswa pada kegiatan praktikum.

c. Modul

Modul yang akan dikembangkan berupa modul fisika berbasis discovery learning pada materi fluida statis. Modul ini yang akan dikembangkan disesuaikan dengan sintaks tersebut dan akan di uji cobakan efektif, valid dan kelayakannya, serta modul ini akan di validasi dan revisi dengan ahli pakar nantinya.

d. Kuesioner atau Angket

Kurnianingtyas, dkk (2012:70) angket atau kuesioner digunakan untuk memperoleh dan mendapatkan data serta mendukung data keaktifan belajar yang dapat diungkap dari diri siswa sendiri. Kuesioner digunakan untuk mendapatkan data tentang kelayakan bahan ajar berupa modul fisika. kuesioner tersebut diperuntukkan bagi ahli materi, ahli media, ahli tata bahasa, serta pembelajaran fisika, dan guru fisika. Kuesioner ini juga digunakan untuk merekam dan melihat respon siswa saat proses uji coba produk dilakukan. Dalam hal ini lembar yang digunakan berupa angket respon siswa yang berisi pertanyaan untuk merekam dan merlihat respon siswa terhadap modul fisika yang dikembangkan. Instrumen ini terlebih dahulu di validasi oleh ahli.

\section{Teknik Analisis Data}

a. Analisis Validasi Materi, Media dan Bahasa Terhadap Modul

Validasi dilakukan dengan menggunakan instrumen angket. Angket yang digunakan merupakan angket terbuka dimana setiap validator dapat memberikan komentar dan sarannya. Angket tersebut menggunakan skala Likert tipe 4. Penilaian dalam angket yang diberikan diberi keterangan seperti, $\mathrm{SB}=$ Sangat Baik, $\mathrm{B}=$ Baik, $\mathrm{K}=$ Kurang, $\mathrm{SK}=$ Sangat Kurang. Validasi ini dilakukan oleh dosen STKIP-PGRI Lubuklinggau dan guru Fisika. Validasi materi dilakukan oleh bapak Ahmad Amin, M.Si. dan ibu Ida Kurnia, M.Pd. Validasi media dilakukan oleh bapak Leo Charli, M.Pd. Validasi tata bahasa dilakukan oleh ibu Dr. Yohana Satinem, M.Pd. Sugiyono (2011) mengemukakan bahwa skor yang telah ditetapkan dapat dihitung sebagai berikut :

$$
\text { Persentase }=\frac{\text { skoryangdiperoleh }}{\text { skormaksimum }} \times 100 \%(1)
$$

b. Analisis Respon Siswa Terhadap Kepraktisan Modul 
Angket yang digunakan pada respon siswa ini menggunakan lembar angket uji coba. Jenis angket yang digunakan yaitu angket terbuka, artinya siswa dapat memberikan penilaian dan komentarnya terhadap kepraktisan modul. angket tersebut menggunakan skala Likert tipe 4 dengan penilaian dalam angket diberikan keterangan seperti, STS = Sangat Tidak Setuju, TS = Tidak Setuju, $\mathrm{S}=$ Setuju, $\mathrm{SS}=$ Sangat Setuju. Pada penilaian angket terdapat kategori positif dan negatif untuk melihat tanggapan tentang pernyataan positif dan negatif yang diberikan oleh peneliti.

Sugiyono (2012) menyatakan bahwa skor yang telah ditetapkan dapat dihitung sebagai berikut:

$$
\text { Presentase }=\frac{\text { skor yang diperole } h}{\text { skor maksimum }} \times 100
$$

\section{c. Analisis Lembar Observasi Aktivitas Siswa}

Untuk menganalisis hasil lembar observasi aktivita siswa yang diisi oleh observer yaitu sebagi berikut:

$$
P=\frac{S}{N} \times 100
$$

Keterangan :

$\mathrm{P}=$ Persentase Penguasaan Setiap Aspek

$\mathrm{S}=$ Jumlah Skor yang diperoleh untuk setiap aspek

$\mathrm{N}=$ Jumlah Skor Total

d. Analisis Pengujian Hipotesis

Untuk menunjukkan bahwa suatu produk yang dikembangkan dapat dikatakan efektif maka harus dilakukan pengujian tes berupa soal esai pada subjek penelitian dalam kelompok yang lebih luas. Soal yang diberikan berjumlah 10 soal dengan tujuan hasil belajar siswa dapat dikatakan tuntas. Pada uji coba kelompok luas melihat ketuntasan hasil belajar siswa penulis akan menggunakan desain One Shot Case Study, dimana peneliti hanya akan melihat hasil akhir pembelajaran yang telah dilaksanakan dengan memberikan modul yang dikembangkan. Hasil akhir yang dilihat digunakan untuk menilai hasil belajar siswa dari segi kognitif siswa. Desain penelitian yang digunakan dapat dilihat pada pola berikut:

$$
\mathrm{X} \quad \mathrm{O}
$$

Sugiyono (2012:110)

Keterangan:

Puplished at https://ojs.stkippgri-lubuklinggau.ac.id/index.php/SJPIF 

$\mathrm{X}$ : Treatment yang diberikan (Variabel indenpenden)
O : Observasi ( Variabel dependen)

\section{HASIL DAN PEMBAHASAN}

Penelitian dilakukan pada siswa kelas XI MIPA 4 di MA Negeri 1 (Model) Lubuklinggau yang dilaksanakan pada tanggal 24 Juli 2019 sampai 07 Agustus 2019 yang melibatkan 39 siswa, terdiri atas 11 siswa laki-laki dan 28 siswa perempuan.

a. Validasi

Hasil penilaian validator terhadap kualitas modul berbasis pendekatan discovery learning pada komponen kelayakan materi memiliki persentase sebesar 79,16\%, sementara itu untuk komponen media memiliki persentase sebesar 76,38 \% dan untuk komponen kebahasaan memiliki persentase sebesar 76,39\%. Persentase keseluruhan komponen validasi adalah 78,81\% sehingga modul berbasis pendekatan discovery learning dikatakan valid dan memenuhi kriteria sangat baik. Berikut

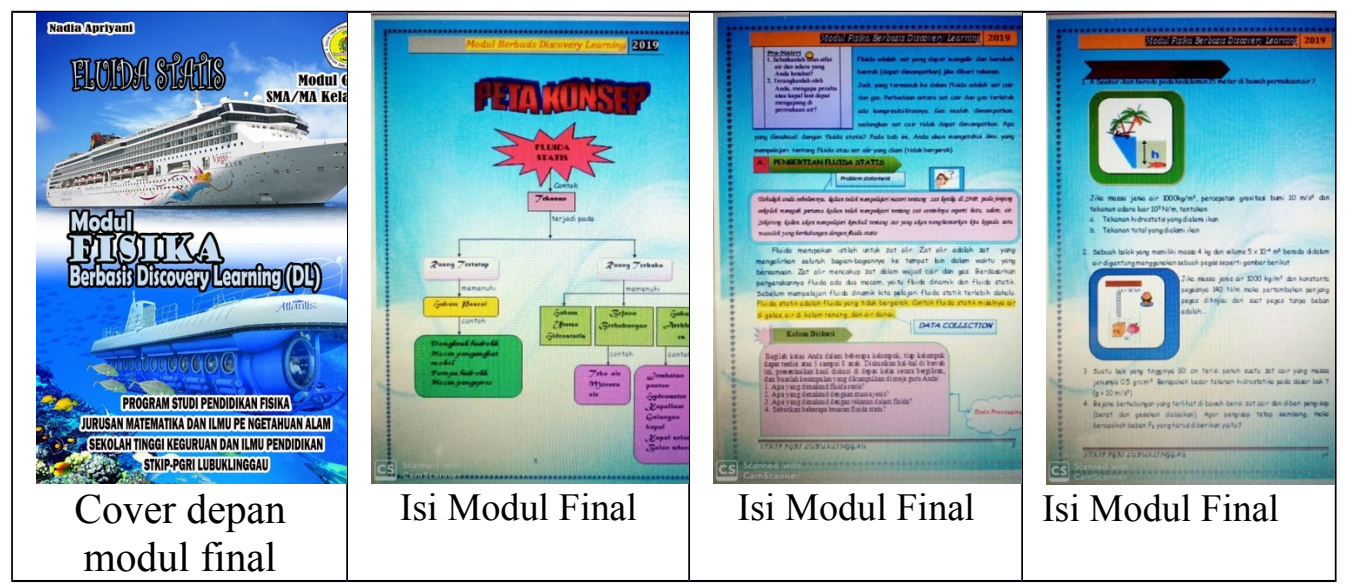

Gambar 2. Modul final yang telah divalidasi

\section{b. Respon Siswa Terhadap Kepraktisan Modul}

Pada tahap uji coba one to one modul berbasis pendekatan scientific didapat hasil dari pelaksanaan tahap uji coba one to one bahwa tidak ada masukan maupun perbaikan dari yang disarankan, sehingga modul dapat digunakan untuk tahap selanjutnya tanpa revisi yang akan diuji kepraktisannya dalam uji coba kelompok kecil. Persentase dari hasil uji coba one to one didapatkan sebesar $86,67 \%$ yang termasuk ke dalam kategori sangat setuju.

Dari hasil uji coba kelompok kecil/terbatas yang telah dilakukan didapatkan hasil yaitu bahwa modul yang dikembangkan sudah baik, menarik dan bagus. Namun terdapat masukan dari siswa bahwa ada pencetakan cover yang kurang sempurna. Berikut hasil revisi modul 
yang dikembangkan berbasis pendekatan discovery learning materi Kesetimbangan dan Dinamika Rotasi berdasarkan masukan dari siswa. Persentase dari hasil uji coba kelompok kecil didapatkan sebesar $88,33 \%$ yang termasuk ke dalam kategori sangat setuju.

Berdasarkan komentar tersebut modul berbasis pendekatan discovery learning yang dikembangkan dapat diproduksi masal tanpa harus direvisi kembali. Untuk saran dan masukan tidak ada lagi, melainkan terdapat komentar dari siswa, akan tetapi komentar tersebut merupakan tanggapan persetujuan atas indikator yang ada. Dengan adanya komentar tersebut, peneliti dapat mengetahui apa yang dipikirkan siswa mengenai modul sedingga modul bisa dikatakan praktis, karena banyaknya siswa yang merespon setuju atas angket kepraktisan modul yang diberikan. Persentase dari hasil uji coba kelompok kecil didapatkan sebesar 79,74\% yang termasuk ke dalam kategori setuju. Dari ketiga uji coba yang dilakukan didapat persentase secara keseluruhan sebesar 84,91\%.

\section{c. Efektivitas Modul Berbasis Pendekatan discovery learning}

Keefektifan adalah hasil guna yang diperoleh setelah pelaksanaan proses belajar mengajar. Efektivitas dikatakan sebagai ukuran untuk mengetahui sejauh mana tujuan secara kualitas (Yolanda, Y., Amin, A., \& Sari, R, 2018). Kuantitas, dan waktu telah dicapai dan efektiitas itu sangat berhubungan dengan pencapaian tujuan bersama bukan pencapaian tujuan pribadi (Nini, 2015:158). Pada penelitian ini ada dua indikator efektivitas yang digunakan yaitu:

1) Hasil belajar tuntas dengan mencapai kriteria ketuntasan $>75 \%$

Berdasarkan penjelasan diatas peneliti telah mendapatkan hasil dari uji coba kelompok luas untuk melihat keefektifan dari modul fisika yang dikembangkan. Keefektifan tersebut dilihat dari hasil belajar siswa. Uji kelompok luas ini dilakukan di kelas XI MIPA 4 SMAN 1 Lubuklinggau dengan menggunakan 1 kelas sebagai subjek dalam penelitian ini. Keefektifan dilihat dari hasil belajar kognitif siswa. Hasil belajar dengan menggunakan soal tes yang berjumlah 10 soal dengan kriteria C3 dan C4. Hasil belajar siswa yang sesuai dengan penelitian yang telah dilakukan di kelas XI MIPA 4 SMAN 1 Lubuklinggau dengan ketuntasan klasikal sebesar 80,55\% yang mampu melebihi nilai minimal 75\% dari jumlah keseluruhan siswa dalam satu kelas. Menurut Sutirto (dalam Jannah, 2016:1200) capaian ini dapat diberi makna bahwa bahan ajar yang dikembangkan telah memberikan dampak terhadap ketuntasan secara klasikal. Sehingga menurut Mubarok dkk (2014:220) menunjukkan hasil belajar dengan model pembelajaran discovery learning memberikan 
pengaruh yang signifikan lebih tinggi daripada pembelajaran langsung atau konvensional. Dengan demikian dapat disimpulkan modul fisika yang dikembangkan telah memenuhi kriteria keefektifan ditinjau dari hasil belajar kognitif produk. Untuk mencapai ketuntasan tersebut terdapat pula nilai rata-rata siswa yang bisa dihitung menggunakan t-test satu sampel. Dimana nilai rata-rata yang didapat berupa, $t_{\text {hitung }}=2,95$ dan $t_{\text {tabel }}=1,689$, karena $t_{\text {hitung }}$ $\geq t_{\text {tabel }}$ maka Ha diterima, dengan demikian rata-rata nilai hasil belajar kognitif siswa dapat dikatakan tuntas. Dari beberapa penjelasan mengenai instrumen yang digunakan untuk mengukur keefektifan dari modul fisika berbasis discovery learning yang dikembangkan maka modul dapat dikatakan efektif karena hasil yang didapat hasil belajar siswa mencapai angka $>70 \%$ dari jumlah keseluruhan siswa di dalam kelas. Widya, dkk (2017:162) menyimpulkan bahwa pembelajaran yang dikatakan efektif bila siswa telah mencapai 75\% dari tujuan pembelajaran yang telah ditetapkan. Soemosasmito dalam Trianto, (dalam Hamka dkk, 2015:59) menyatakan bahwa suatu pembelajaran dikatakan efektif apabila memenuhi persyaratan utama keefektifan pengajaran, yaitu:

a. Presentasi waktu belajar siswa yang tinggi dicurahkan terhadap KBM.

b. Rata-rata perilaku melaksanakan tugas yang tinggi diantara siswa.

c. Ketetapan antara kandungan materi pelajaran dengan kemampuan siswa (orientasi keberhasilan belajar) diutamakan.

d. Mengembangkan suasana belajar yang akrab dan positif, mengembangkan struktur kelas yang mendukung butir (2) tanpa mengabaikan butir (4).

2. Aktivitas siswa dalam kegiatan praktikum

Berdasarkan hasil penelitian mengukur aktivitas pembelajaran siswa pada saat kegiatan praktikum. Langkah-langkah proses kegiatan pada saat praktikum dilakukan untuk melihat keefektifan modul fisika berbasis discovery learning, dimana langkah-langkah terebut menerapkan enam sintaks yang ada pada modul tersebut. Sintaks yang ada pada modul meliputi stimulation, problem statement, data collection, data processing, verification dan generalization. Pada saat praktikum dilakukan pengamatan suatu kegiatan yang melibatkan 5 observer untuk menilai aktivitas masing-masing siswa. Di dalam kegiatan praktikum digunakan instrument penilaian aktivitas siswa pada saat praktikum menggunakan enam sintaks yang terdiri dari 10 butir soal.

Adapun hasil rata-rata persentase aktivitas siswa pada saat kegiatan praktikum dalam bentuk tabel menggunakan ke enam sintaks discovery learning dapat dilihat pada tabel 4.27 di bawah ini: 
Tabel 1. Hasil Rata-Rata Persentase Aktivitas Siswa Pada Saat Praktikum

\begin{tabular}{llcccc}
\hline $\begin{array}{c}\text { No. } \\
\text { Sintaks Discovery } \\
\text { Learning }\end{array}$ & $\begin{array}{c}\text { Nomor } \\
\text { Pertanyaan }\end{array}$ & Persentase & Rata-rata & $\begin{array}{c}\text { Rata- } \\
\text { rata } \\
\text { Skor }\end{array}$ \\
\hline 1. & Stimulation & 1 & $75 \%$ & $75 \%$ & $71,4 \%$ \\
2. & Problem Statement & 2 & $72 \%$ & $72 \%$ & \\
3. Data Collection & 3 & $72,91 \%$ & $71,18 \%$ & \\
& & 4 & $75,69 \%$ & & \\
& & 5 & $69,44 \%$ & & \\
4. Data Processing & 6 & $66,67 \%$ & & \\
5. & Verification & 8 & $71,52 \%$ & $71,52 \%$ & \\
6. Generalization & 9 & $72,22 \%$ & $72,22 \%$ & \\
& & 10 & $70,83 \%$ & $69,09 \%$ & \\
\end{tabular}

Berdasarkan pada tabel di atas hasil yang didapat menggunakan keenam sintaks discovery learning yaitu: 1) stimulation hasil rata-rata persentase yang didapat mencapai $75 \%$ dengan kategori baik, 2) problem statement dengan hasil rata-rata persentase mencapai $72 \%$ termasuk kategori baik, 3) data collection hasil rata-rata persentase mencapai $71,18 \%$ dengan kategori baik, 4) data processingrata-rata persentase mencapai 71,52\% dengan kategori baik, 5) verificationhasil rata-rata persentase mencapai 72,22\% dengan kategori baik, dan 6) generalizationhasil rata-rata persentase mencapai 69,09\% dengan kategori baik. Sedangkan hasil rekapitulasi penilaian aktivitas siswa pada praktikum secara keseluruhan yaitu mencapai $71,4 \%$ dengan kategori baik. Hal ini bisa dikatakan keefektifan dalam modul fisika berbasis discovery learning dikategorikan aktif dan baik.

\section{SIMPULAN}

Berdasarkan penelitian, peneliti menyimpulkan bahwa:

1. Peneliti mengembangkan modul fisika dengan menggunakan model pembelajaran discovery learning yaitu model pembelajaran dengan cara menemukan. Pengembangan modul fisika berbasis discovery learning yang dilakukan melalui 4 tahap tahapan mulai dari define, design, develop dan disseminate.

2. Hasil penilaian kelayakan terhadap kualitas modul fisika berbasis discovery learning secara keseluruhan adalah 78,81\% sehingga modul fisika berbasis discovery learning dikatakan valid dan memenuhi kriteria baik. Persentase keseluruhan respon siswa terhadap modul fisika berbasis discovery learning adalah $86,68 \%$ sehingga modul dikatakan praktis dan memenuhi kriteria sangat setuju atau positif. Hasil penilaian keefektifan terhadap modul fisika berbasis discovery learning pada persentase hasil tes 
ulangan harian sebesar $80,55 \%$ siswa yang memperoleh nilai di atas 70 ada 29 siswa dan 7 siswa nilainya dibawah 70 dari 10 butir soal tes sehingga modul fisika dikatakan efektif. Dimana nilai rata-rata yang didapat berupa, $\mathrm{t}_{\text {hitung }}=2,95$ dan $\mathrm{t}_{\text {tabel }}=1,689$, karena $t_{\text {hitung }} \geq t_{\text {tabel }}$. Sehingga dapat dikatakan Ha diterima dan Ho ditolak karena rata-rata nilai hasil ulangan siswa kelas XI MIPA 4 adalah 83,8 yang nilainya $>70$. Oleh karena itu, modul fisika berbasis discovery learning pada materi fluida statis dapat dikatakan valid, praktis dan efektif.

\section{DAFTAR PUSTAKA}

Ain, Trise Nurul. (2013). Pemanfaatan Visualisasi Video Percobaan Gravity Current Untuk Meningkatkan Pemahaman Konsep Fisika Pada Materi Tekanan Hidrostatis. Jurnal Inovasi Pendidikan Fisika. 2 (2), 97 - 102.

Ariani, T. (2017). Penerapan Strategi Pembelajaran Ekspositori Untuk Meningkatkan Hasil Belajar Fisika. Jurnal Inovasi dan Pembelajaran Fisika, 4(1), 19-26.

Arikunto, S. (2010). Prosedur Penelitian Suatu Pendekatan Praktik. Jakarta: Rineka Cipta.

Asyhar, Rayandra, M.Si. (2011). Kreatif Mengembangkan Media Pembelajaran. Jakarta: Gaung Persada.

Ayu, W. R., Ariani, T., \& Arini, W. (2019). The Effect of Quantum Teaching Learning Model on the Physics Learning Outcomes of Class X SMK Negeri 3 Lubuklinggau. Kasuari: Physics Education Journal (KPEJ), 2(1), 36-48.

Daryanto. (2013). Menyusun Modul (Bahan Ajar untuk Persiapan Guru dalam Mengajar). Yogyakarta: Gava Media.

Haryati, Sri. (20120. Research And Development (R\&D) Sebagai Salah Satu Model PenelitianDalam Bidang Pendidikan. Research And Development (R\&D). 37(1), 11-26.

Hidayat, Badi Rahmad, Dkk. (2013). Analisis Kesalahan Siswa Dalam Menyelesaikan Soal Pada Materi Ruang Dimensi Tiga Ditinjau Dari Gaya Kognitif Siswa (Penelitian Dilakukan Di SMA Negeri 7 Surakarta Kelas X Tahun Ajaran 2011/2012). Jurnal Pendidikan Matematika Solusi 1(1), 39-46.

Lorenza, Y., Sasmita, P. R., \& Amalia, S. (2019). Pengaruh Model Pembelajaran Inkuiri Terbimbing Berbantukan Alat Peraga Sederhana Terhadap Hasil Belajar Fisika Peserta Didik. SILAMPARI JURNAL PENDIDIKAN ILMU FISIKA, 1(2), 87-93.

Mulyatiningsih, Dr. Endang. (2014). Metode Penelitian Terapan Bidang Pendidikan. Yogyakarta: ALVABETA,cv.

Nini, Wa Ode, dkk. (2015). Efektivitas Penerapan Model Pembelajaran Kooperatif Tipe Think Pair Share Terhadap Hasil Belajar Matematika Materi Pokok Statistika Pada Siswa Kelas IX SMP Negeri 2 Kendari. Jurnal Penelitian Pendidikan Matematika 3(1), 153-166.

Puplished at https://ojs.stkippgri-lubuklinggau.ac.id/index.php/SJPIF 
Pribowo, Fitroh Setyo P. (2017). Pengembangan Bahan Ajar Mata Kuliah Ipa Berbasis Pendekatan Scientific Approach. Jurnal Pendidikan Pedagogia 6(1), 54-66.

Sudijono, Anas. (2013). Pengantar Evaluasi Pendidikan. Jakarta: PT Raja grafindo Persada.

Sugiyono. (2011). Metode Penelitian Kuantitatif, Kualitatif dan R\&D. Bandung: Alfabeta.

Sulistyaningrum, Dyah Erlina, dkk. (2015). Pengembangan Modul Berbasis Model Pembelajaran Arias Untuk Memberdayakan Motivasi Dan Berpikir Kritis Siswa Pada Materi Ekosistem. Jurnal Inkuiri. 4(01), 106.

Sumiati, Eli, dkk. (2018). Pengembangan Modul Fisika Berbasis Scientific Approach untuk Meningkatkan Keterampilan Proses Sains Siswa. Jurnal Pendidikan Fisika dan Keilmuan (JPFK) 4(2), 75-88.

Trianto. 2010. Model Pembelajaran Terpadu. Jakarta: Bumi Aksara.

Widya, dkk,. 2017. Kualitas Perangkat Pembelajaran Fisika Berbasis Model Creative Problem Solving Dengan Pendekatan Open - Ended Pada Materi Usaha Dan Energi Terintegrasi Energi Biomassa. Gravity: Jurnal Ilmiah Penelitian dan Pembelajaran Fisika. 3 (2), 162, 164 dan 166.

Wynarti, Indah Agustina. (2018). Pengembangan Permainan Charades Sebagai Media Pembelajaran Materi Jenis-jenis Bisnis Ritel Kelas XI Pemasaran di SMK Negeri 2 Buduran. Jurnal Pendidikan Tata Niaga (JPTN). 6 (3), 63-70.

Yuliani, N., Amin, A., \& Arini, W. (2019). Perbandingan Model Pembelajaran Kooperatif Tipe Student Teams Achievement Division (STAD) dengan Metode Diskusi Kelas X Sma Negeri 1 Model Muara Beliti Tahun Pelajaran 2018/2019. SILAMPARI JURNAL PENDIDIKAN ILMU FISIKA, 1(1), 38-51.

Yolanda, Y., Amin, A., \& Sari, R. (2018). Efektivitas Pendekatan Scientific pada Pembelajaran Fisika. Jurnal Perspektif Pendidikan, 12(2), 21-30. 